\title{
Population and Diversity of Endophytic Bacteria Associated with Medicinal Plant Curcuma zedoaria
}

\author{
TRI RATNA SULISTIYANI ${ }^{1,2}$, PUSPITA LISDIYANTI $^{3}$, AND YULIN LESTARI ${ }^{1,4 *}$
}

\author{
'Department of Biology, Faculty of Mathematic and Natural Sciences, Institut Pertanian Bogor, \\ Dramaga Campus, Bogor 16680, Indonesia; \\ ${ }^{2}$ Research Center for Biology, Indonesian Institute of Sciences, Cibinong Science Center, Cibinong 16911, Indonesia; \\ ${ }^{3}$ Research Center for Biotechnology, Indonesian Institute of Sciences, Cibinong Science Center, Cibinong 16911, Indonesia; \\ ${ }^{4}$ Biopharmaca Research Center, Institut Pertanian Bogor, Bogor 16151, Indonesia
}

Traditionally Curcuma zedoaria (white turmeric) known as herbal medicine which possessing many biological activities. Many endophytic bacteria live in association with their host and may play an important biological roles. The main interest of this study was to investigate the endophytic bacterial diversity associated with white turmeric. White turmerics were collected from three locations in Bogor, West Java, Indonesia. The isolation of endophytic bacteria was carried out using 4 kinds media (Nutrient Agar (NA), NA contained white turmeric extract (NAT), Water Yeast Extract Agar (WYEA), WYEA contained white turmeric extract (WYEAT)), and 2 methods of spread plate and plant piece methods. The identification of selected isolates was conducted by molecular analysis based on $16 \mathrm{~S}$ rDNA. The suitable media and method of isolation endophytic bacteria were NA and spread plate method. A total of 207 bacterial colonies were isolated from rhizomes, stems, and leaves and 73 endophytic bacteria were selected based on morphological characteristics. From them, $32 \%$ isolates from Bojong Gede, $22 \%$ isolates from Cibinong and $46 \%$ isolates from Dramaga were obtained. Endophytic bacteria were predominated $38 \%$ in the rhizomes, $32 \%$ of stems, and $30 \%$ of leaves. Based on $16 \mathrm{~S}$ rDNA sequence analysis, the isolates were belonging to the cluster Alphaproteobacteria, Betaproteobacteria, Gammaproteobacteria, Firmicutes, and Actinobacteria, with twenty three different genera includes Stenothropomonas, Pseudomonas, Enterobacter, Providencia, Klebsiella, Dickeya, Pantoea, Bacillus, Acinetobacter, Citrobacter, Mycobacterium, Cellulomonas, Microbacterium, Methylobacterium, Penylobacterium, Roseomonas, Agrobacterium, Bosea, Xanthobacter, Rhizobium, Burkholderia, Ralstonia, and Alcaligenes. The plant location, age, part of plant, media and method of isolation seem to influence the endophytic bacterial communities.

Key words: 16S rDNA, Curcuma zedoaria, diversity, endophytic bacteria, population

Secara tradisional kunyit putih merupakan tanaman herbal yang banyak digunakan untuk pengobatan penyakit terutama yang berhubungan dengan kanker. Bakteri endofit banyak ditemukan hidup dalam jaringan tanaman inang dan memainkan peran biologi yang penting. Penelitian ini bertujuan untuk mengkaji keragaman bakteri endofit yang berasosiasi dengan tanaman kunyit putih (Curcuma zedoaria). Tanaman kunyit putih diambil dari tiga lokasi yang berbeda di Bogor, Jawa Barat, Indonesia. Isolasi bakteri endofit dilakukan menggunakan 4 macam media (Nutrient Agar (NA), NA dengan ekstrak kunyit putih (NAT), Water Yeast Extract Agar (WYEA), WYEA dengan ekstrak kunyit putih (WYEAT)) dan 2 metode yaitu metode sebar dan potongan tanaman. Identifikasi isolat terseleksi menggunakan analisis molekuler berdasarkan 16S rDNA. Media dan metode isolasi bakteri endofit yang cocok adalah media NA dan metode sebar. Sebanyak 207 isolat telah berhasil diisolasi dari bagian akar, batang dan daun. Sebanyak 73 isolat yang berbeda dari 207 isolat dipilih berdasarkan perbedaan karakteristik morfologi. Tiga puluh dua persen isolat diperoleh dari Bojong Gede, $22 \%$ isolat dari Cibinong dan 46\% isolat berasal dari Dramaga. Bakteri endofit didominasi oleh bakteri dari rimpang yaitu sebanyak 38\%, 32\% dari batang, dan 30\% dari daun. Berdasarkan hasil analisis sekuen $16 \mathrm{~S}$ rDNA, bakteri yang diperoleh termasuk dalam kluster Alphaproteobacteria, Betaproteobacteria, Gammaproteobacteria, Firmicutes, dan Actinobacteria, dengan 23 genus yang berbeda yaitu Stenothropomonas, Pseudomonas, Enterobacter, Providencia, Klebsiella, Dickeya, Pantoea, Bacillus, Acinetobacter, Citrobacter, Mycobacterium, Cellulomonas, Microbacterium, Methylobacterium, Penylobacterium, Roseomonas, Agrobacterium, Bosea, Xanthobacter, Rhizobium, Burkholderia, Ralstonia, and Alcaligenes. Lokasi, usia, bagian tanaman, media dan metode isolasi berpengaruh terhadap komunitas bakteri endofit yang diketahui dari suatu tanaman.

Kata kunci : 16S rDNA, bakteri endofit, Curcuma zedoaria, keragaman, populasi

The endophytic microbes have been known as secondary metabolites producers which have several

*Corresponding author; Phone: +62-251-8622833, E-mail: yulinlestari@gmail.com. potential applications in pharmaceutical industry. Some of the endophytic microbes can produce the same bioactive compounds as that of the plant thus making them as a promising source of novel 
compounds, such as anticancer, antibiotic, antimycotic and antiviral (Christina et al. 2013). Population and profile of endophytic microbes are influenced by location of the host plants (Procopio et al. 2009), environmental conditions, plants species, and plants age (Dalal and Kulkarni 2013). Plants that used by human as a traditional medicine with high etnobotanical history are possessing great biodiversity of endophytic microbes.

Zingiberaceae is a family of the important medicinal plants. Many compounds have been detected in Zingiberaceae species, such as, turmerin, sesquiterpenes, steroid and essential oils (Joy et al. 1998). Several important genera belong to the ginger family are Curcuma, Kaempferia, Hedychium, Amomum, Zingiber, Alpinia, Elettaria, Costus, and each having different compounds which can be used in pharmaceutical industry. One of the ginger family that interesting to be investigated for their endophytic bacteria is Curcuma spp. Curcuma zedoaria known as white turmeric is traditionally used as herbal medicine to treat diseases related to cancer. In addition, several studies showed that white turmeric has pharmacological effects of antibacterial (Banisalam et al. 2011), anticancer and antioxidants (Muthu-kumar et al. 2012). According to Lakshmi et al. (2011), essential oil from the rhizome of white turmeric has activity to inhibit the proliferation of cancer cells.

Several endophytic microbes have been isolated which are able to produce various bioactive compounds. Pseudomonas, Bacillus, and Burkholderia were the most commonly isolated bacterial genera and potential as a bioactive compounds producer. Taxol as the world's first billion dollar anticancer drug was produced by fungus Taxomyces andreanae from the yew Taxus brevifolia (Ryan et al. 2007). Bacillus amyloliquefaciens from
Ophiopogon japonicus showed antitumor activity against gastric carcinoma cell lines (Chen et al. 2013), endophytic microbes from the rhizome of $C$. zeodaria produced antimicrobes compound (Srikandace et al. 2007). Actinomycetes which was isolated from rhizome of Curcuma aeruginosa had alpha glucosidase inhibition activity (Pujiyanto et al. 2012).

Natural products produced by endophytic bacteria can be applied as a foundation for the development of therapeutic agents. Many researches have explored the potential of endophytic bacteria as source of bioactive compounds producer, however, information on the diversity of endophytic bacteria of a particular plant has not been studied in depth. In Indonesia, the study on the diversity and activity of endophytic bacteria to produce several bioactive compounds in white turmeric has not been done. The main objective of the study was to explore the diversity of endophytic bacteria in white turmeric from three locations based on molecular identification of $16 \mathrm{~S}$ rDNA sequences.

\section{MATERIALS AND METHODS}

Plant Materials. White turmerics (C. zedoaria) were collected from three locations in Bogor, West Java, Indonesia. The plants materials collected from private garden in Bojong Gede (BG), experiment garden of Research Center for Biology, Indonesian Institute of Sciences, Cibinong (CBN) and garden of medicinal plants collection of Biopharmaca Research Center, Bogor Agricultural University, Dramaga (DRMG) (Table 1). White turmeric plants were identified based on the morphological characteristics at the Herbarium Bogoriense, Indonesian Institute of Sciences, Cibinong, Indonesia. From each plant materials, rhizome, stem, and leaf were collected for endophytic bacteria isolation.

Table 1 Characteristics identity of white turmeric plants used in this research

\begin{tabular}{|c|c|c|c|c|c|}
\hline $\begin{array}{l}\text { Original plants } \\
\text { sources }\end{array}$ & Sampling locations & $\begin{array}{l}\text { Plant age } \\
\text { (month) }\end{array}$ & Part of plants & Family & Species \\
\hline $\begin{array}{l}\text { Cim anggu, } \\
\text { Bogor }\end{array}$ & $\begin{array}{l}\text { Bojong Gede } \\
\text { (BG) }\end{array}$ & 11 & $\begin{array}{c}\text { Rhizome, stem, } \\
\text { leaf }\end{array}$ & Zingiberaceae & $\begin{array}{l}\text { Curcuma zedoaria } \\
\text { (Christm.) Roscoe }\end{array}$ \\
\hline $\begin{array}{l}\text { Rimbo Panti, } \\
\text { Padang }\end{array}$ & $\begin{array}{c}\text { Research Center for } \\
\text { Biology, }(\mathrm{CBN})\end{array}$ & 8 & $\begin{array}{c}\text { Rhizome, stem, } \\
\text { leaf }\end{array}$ & Zingiberaceae & $\begin{array}{l}\text { Curcuma zedoaria } \\
\text { (Christm.) Roscoe }\end{array}$ \\
\hline $\begin{array}{l}\text { Cimas, } \\
\text { Sukabumi }\end{array}$ & $\begin{array}{c}\text { Biopharm aca } \\
\text { Research Center, } \\
\text { (DRMG) }\end{array}$ & 12 & $\begin{array}{c}\text { Rhizome, stem, } \\
\text { leaf }\end{array}$ & Zingiberaceae & $\begin{array}{l}\text { Curcuma zedoaria } \\
\text { (Christm.) Roscoe }\end{array}$ \\
\hline
\end{tabular}


Surface Sterilization of Rhizomes, Stems, and Leaves. Rhizomes, stems, and leaves were thoroughly washed to remove external soil and microbes using running tap water for 5-10 min. Surface sterilization was done by stepwise soaking using $70 \%$ etanol solution for $3 \mathrm{~min}, 3 \%(\mathrm{v} / \mathrm{v})$ sodium hypochloride for 5 min, 70\% etanol solution for $30 \mathrm{~s}$, and followed by three times rinsing with sterile distilled water. The samples were dried using sterilized towel tissue.

Isolation of Endophytic Bacteria. Endophytic bacteria isolation was done by plant piece and spread plate methods. Rhizomes, stems and leaves were cut using sterile knife approximately into 4-6 $\mathrm{mm}$ pieces. In the plant piece method, pieces of samples were placed on four different media, Nutrient Agar (NA), NA contained $2 \%$ white turmeric plant extract (NAT), Water Yeast Extract Agar (WYEA), and WYEA contained 2\% white turmeric plant extract (WYEAT). The media were supplemented with cycloheximide 50 $\mu \mathrm{g} \mathrm{mL}{ }^{-1}$ to avoid the growth of fungi. Plates were incubated at $28^{\circ} \mathrm{C}$ for $2-15$ days. In spread plate method, isolation of endophytic bacteria was done by grinding $1 \mathrm{~g}$ of samples in $9 \mathrm{~mL}$ of sterilized distilled water and $100 \mu \mathrm{L}$ of $10^{-1}$ and $10^{-2}$ serial dilutions were spreaded on four different media same as above. The plates were incubated at $28^{\circ} \mathrm{C}$ for $2-15$ days. Bacterial colonies which appeared on the media in a spread plate method were counted and expressed in colony forming units (CFU) per gram, and population data were transformed to log (CFU per gram sample (CFU g ${ }^{-1}$ ). Some endophytic bacterial isolates which grew both on the media using spread plate and plant piece methods were picked up based on several phenotypic characteristics and then purified to obtain a single colony. Based on their different morphological characteristics, the endophytic bacteria were selected for further studies. Phenotypic characteristics which were used to observe the colony were: color, surface, the margin of the colony and gram reaction using $\mathrm{KOH}$ test.

DNA Extraction and Amplification of 16S rDNA. DNA extraction was conducted by colony PCR method (Packeiser et al. 2013) using Gradient PCR machines (Eppendorf Mastercycler Gradient PCR System 5331). Amplification of $16 \mathrm{~S}$ rDNA was performed by PCR using primer pair of 27F (5'AGAGTTTGATCCTGGCTCAG-3') and 1492R (5'GGTTACCTTGTTACGACTT-3') (Palaniappan et al. 2010). The $16 \mathrm{~S}$ rDNA amplification was carried out in a total volume of $25 \mu \mathrm{L}$ containing Ultrapure water, GoTaq Green Master Mix, $10 \mu \mathrm{M}$ of each primer, dimethyl sulfoxide (DMSO), and DNA template. The PCR conditions was set as follows: initial denaturation at $95^{\circ} \mathrm{C}$ for $90 \mathrm{~s}$, followed by 30 cycles of denatura-tion at $95^{\circ} \mathrm{C}$, for $30 \mathrm{~s}$; annealing at $50^{\circ} \mathrm{C}$, for $30 \mathrm{~s}$; elongation at $72{ }^{\circ} \mathrm{C}$, for $90 \mathrm{~s}$ and final extension at $72{ }^{\circ} \mathrm{C}$ for $5 \mathrm{~min}$, finally at $4{ }^{\circ} \mathrm{C}$ for $20 \mathrm{~min}$. PCR products were analyzed using $1 \%$ agarose gel. Gel was soaked in ethidium bromide solution $\left(5 \mu \mathrm{gmL}^{1}\right)$ for $30 \mathrm{~min}$, rinsed with $1 \mathrm{X}$ TAE buffer, and the results were detected using a UV transilluminator.

DNA Sequencing and Phylogenetic Analysis. The amplified DNA were partially sequenced using forward primer $27 \mathrm{~F}$ by automated DNA sequencer (ABI PRISM 3130 Genetic Analyzer) (Applied Biosystems). The sequenced data were processed using Bioedit programme. The homology of $16 \mathrm{~S}$ rDNA sequence were searched using BLASTN at the NCBI website and the references sequence was obtained from the GenBank (www.ncbi.nlm.nih.gov). Constructions of phylogenetic tree was done using neighbor-joining tree method (NJT) implemented in MEGA 5.05 software (Tamura et al. 2011). Model of $\mathrm{K} 2+\mathrm{G}+\mathrm{I}$ (Kimura2-parameter and Gamma distributed) was selected as the best-fit substitution model for the current analysis. Strength of internal branches of the phylogenetic tree was tested with boostrap analysis using 1000 replications.

\section{RESULTS}

Plant Materials Identity. Observation of morphological characters of white turmeric plant was done referred to the plant identification book of Flora of Java and compared to herbarium specimen in the Herbarium Bogoriense. Based on the morphological characteristics, all samples were identified as $C$. zedoaria (Christm.) Roscoe, the member of the genus Curcuma in the family of Zingiberaceae (Table 1).

Population of Endophytic Bacteria Associated with $C$. zedoaria. The population of endophytic bacteria contained in white turmeric plants differed between location, age, rhizome, stem and leaf, and also influenced by media and method of isolation. Based on the data presented in Fig 1, three plant materials showed to have different endophytic bacterial population ranging from 2 to $4 \log \left(\mathrm{CFU} \mathrm{g} \mathrm{g}^{-1}\right)$. The number of isolates obtained by spread plate method were higher compared to plant piece method (Table 2). The most effective media and method of isolation endophytic bacteria from white turmeric plant were NA and spread plate method. The highest population of 
endophytic bacteria was found in samples that collected from DRMG and among the part of plant, rhizome showed the highest population of endophytic bacteria. Two hundred and seven endophytic bacteria were isolated from different parts of white turmeric plants.

Based on the morphological characteristics of 207 isolates, 73 were selected for further studies. Among the 73 selected isolates, 23 isolates from BG (32\%), 16 from CBN (22\%) and 34 from DRMG (46\%). Furthermore, 28 isolates were obtained from rhizomes $(38 \%), 23$ isolates from stems (32\%) and 22 isolates from leaves (30\%). The Gram reaction results showed that 49 isolates were Gram-negative and 24 isolates were Gram-positive bacteria (Table 3). Both of Grampositive and negative bacteria were found in all samples and bacteria from the rhizomes, stems and leaves were dominated by Gram negative bacteria.

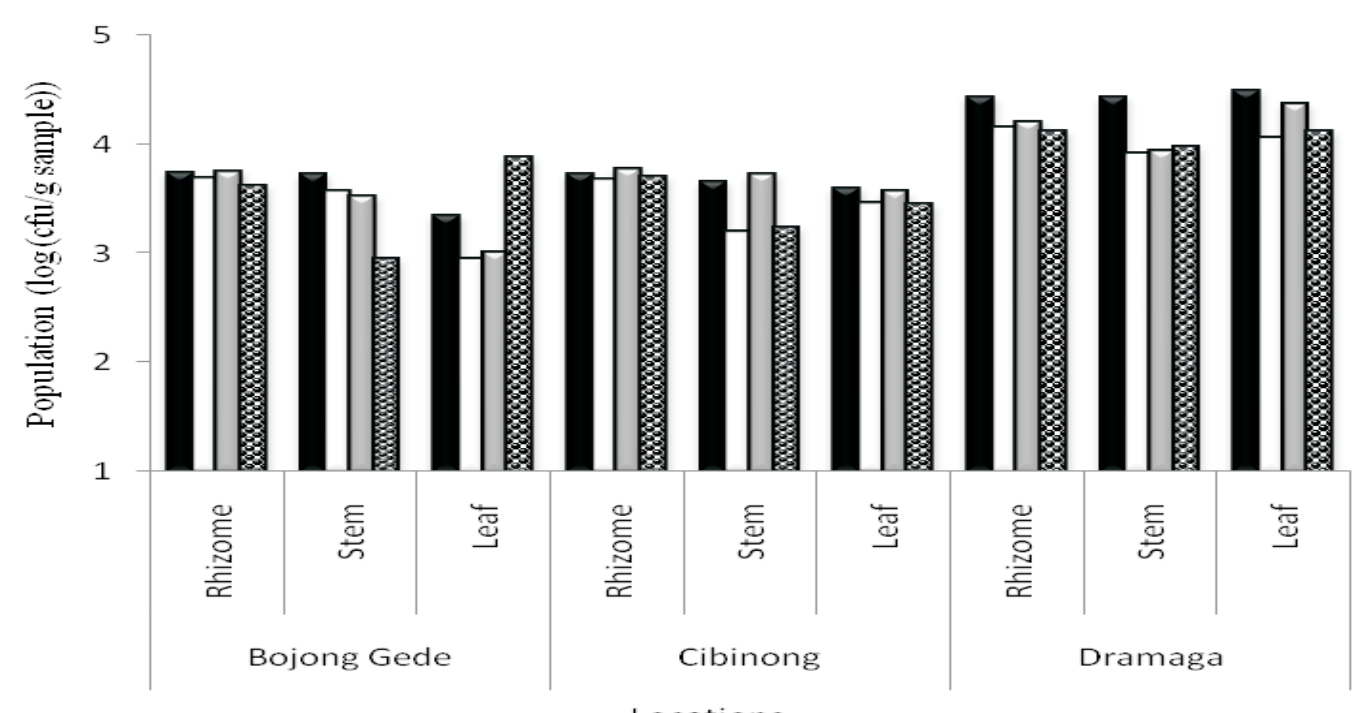

Fig 1 The population of white turmeric endophytic bacteria from three sampling locations based on spread plate method, $\square$ NA, $\square$ NAT, $\square$ WYEA, 圆WYEAT.

Table 2 The number of selected endophytic bacterial isolates obtained from white turmeric using spread plate and plant piece methods

\begin{tabular}{|c|c|c|c|c|c|c|c|c|c|}
\hline & & \multicolumn{2}{|c|}{ NA } & \multicolumn{2}{|c|}{ NAT } & \multicolumn{2}{|c|}{ WYEA } & \multicolumn{2}{|c|}{ WYEAT } \\
\hline & & $\mathrm{S}$ & $\mathrm{P}$ & $\mathrm{S}$ & $\mathrm{P}$ & $\mathrm{S}$ & $\mathrm{P}$ & S & $\mathrm{P}$ \\
\hline \multirow{3}{*}{$\begin{array}{l}\text { Bojong } \\
\text { Gede }\end{array}$} & Rhizome & 6 & - & 1 & 3 & 2 & 1 & 1 & - \\
\hline & Stem & 7 & 2 & 2 & 3 & 2 & 2 & 3 & 1 \\
\hline & Leaf & 4 & 4 & 7 & 3 & 4 & 2 & 8 & 2 \\
\hline \multirow{3}{*}{ Cibinong } & Rhizome & 2 & - & 3 & 3 & 1 & 1 & 1 & 1 \\
\hline & Stem & 3 & 5 & 1 & 3 & 4 & - & 2 & 2 \\
\hline & Leaf & 5 & 6 & 1 & 6 & 4 & - & 3 & - \\
\hline \multirow{4}{*}{ Dramaga } & Rhizome & 4 & 4 & 4 & 5 & 5 & 2 & 4 & 2 \\
\hline & Stem & 5 & 4 & 3 & 4 & 3 & 2 & 4 & 3 \\
\hline & Leaf & 3 & 2 & 2 & 4 & 3 & 2 & 5 & 1 \\
\hline & & 39 & 27 & 24 & 34 & 28 & 12 & 31 & 12 \\
\hline Total & & & & & 207 & & & & \\
\hline
\end{tabular}

S: Spread plate method; P: Plant piece method 
Molecular Identity of Endophytic Bacteria Based on Partial Sequencing of 16S rDNA. Based on the results of partial sequencing of about $700-1200 \mathrm{bp}$ and analysis of $16 \mathrm{~S}$ rDNA, the 73 isolates showed high similarities between $97 \%$ to $100 \%$ with the data bases in GenBank. The molecular identification of all isolates into species level were presented in Table 3. According to phylogenetic tree analysis, the isolates widely distributed to the cluster of Alphaproteobacteria,
Betaproteobacteria, Gammaproteobacteria, Firmicutes, and Actinobacteria, with twenty three different genera, including Stenothropomonas, Pseudomonas, Enterobacter, Providencia, Klebsiella, Dickeya, Pantoea, Bacillus, Acinetobacter, Citrobacter, Mycobacterium, Cellulomonas, Microbacterium, Methylobacterium, Penylobacterium, Roseomonas, Agrobacterium, Bosea, Xanthobacter, Rhizobium, Burkholderia, Ralstonia, and Alcaligenes (Fig 2).

Table 3 Diversity of endophytic bacteria from white turmeric plants based on 16S rDNA analysis

\begin{tabular}{|c|c|c|c|c|c|}
\hline & $\begin{array}{l}\mathrm{KO} \\
\mathrm{H} \\
\text { test }\end{array}$ & Bojong Gede & $\begin{array}{l}\text { Research Center for Biology, } \\
\text { Cibinong }\end{array}$ & $\begin{array}{c}\text { Biopharmaca Research Center, } \\
\text { Dramaga }\end{array}$ & Total \\
\hline \multirow[b]{2}{*}{ Rhizome } & + & $\begin{array}{l}\text { 1. Bacillus subtilis } \\
\text { 2. Cellulomonas } \\
\text { hominis }\end{array}$ & 1. Bacillus safensis & $\begin{array}{l}\text { 1. Microbacterium } \\
\text { trichothecenolyticum } \\
\text { 2. Bacillus cereus }\end{array}$ & 5 \\
\hline & - & $\begin{array}{l}\text { 1. Klebsiella } \\
\text { pneumoniae } \\
\text { 2. Pseudomonas } \\
\text { denitrificans } \\
\text { 3. Pseudomonas } \\
\text { stutzeri } \\
\text { 4. Pantoea dispersa } \\
\text { 5. Klebsiella variicola } \\
\text { 6. Bosea thiooxidans }\end{array}$ & $\begin{array}{l}\text { 1. Providencia vermicola } \\
\text { 2. Phenylobacterium koreense } \\
\text { 3. Enterobacter aerogenes } \\
\text { 4. Roseomonas mucosa }\end{array}$ & $\begin{array}{l}\text { 1. Burkholderia cenocepacia } \\
\text { 2. Burkholderia phenoliruptrix } \\
\text { 3. Enterobacter cloacae } \\
\text { 4. Enterobacter ludwigii } \\
\text { 5. Pantoea dispersa } \\
\text { 6. Pantoea agglomerans } \\
\text { 7. Pseudomonas geniculata } \\
\text { 8. Pseudomonas gessardii } \\
\text { 9. Pseudomonas nitroreducens } \\
\text { 10. Stenotrophomonas } \\
\text { maltophilia } \\
\text { 11. Klebsiella pneumoniae } \\
\text { 12. Klebsiella variicola } \\
\text { 13. Acinetobacter } \\
\text { calcoaceticus }\end{array}$ & 23 \\
\hline \multirow[t]{2}{*}{ Stem } & + & $\begin{array}{l}\text { 1. Microbacterium } \\
\text { laevaniformans } \\
\text { 2. Microbacterium } \\
\text { trichothecenolyticum } \\
\text { 3. Microbacterium } \\
\text { hominis } \\
\text { 4. Mycobacterium } \\
\text { simiae } \\
\text { 5. Bacillus pumilus }\end{array}$ & $\begin{array}{l}\text { 1. Bacillus safensis } \\
\text { 2. Mycobacterium cosmeticum }\end{array}$ & $\begin{array}{l}\text { 1. Microbacterium resistens } \\
\text { 2. Bacillus cereus } \\
\text { 3. Microbacterium } \\
\text { laevaniformans }\end{array}$ & 10 \\
\hline & - & $\begin{array}{l}\text { 1. Klebsiella } \\
\text { pneumoniae } \\
\text { 2. Erwinia chrysanthemi } \\
\text { 3. Xanthobacter flavus } \\
\text { 4. Enterobacter oryzae }\end{array}$ & $\begin{array}{l}\text { 1. Stenotrophomonas } \\
\text { maltophilia } \\
\text { 2. Pseudomonas otitidis }\end{array}$ & $\begin{array}{l}\text { 1. Stenotrophomonas } \\
\text { maltophilia } \\
\text { 2. Enterobacter ludwigii } \\
\text { 3. Acinetobacter calcoaceticus } \\
\text { 4. Ralstonia mannitolilytica } \\
\text { 5. Klebsiella variicola } \\
\text { 6. Citrobacter freundii } \\
\text { 7. Pseudomonas moraviensis }\end{array}$ & 13 \\
\hline \multirow{2}{*}{ Leaf } & + & $\begin{array}{l}\text { 1. Microbacterium } \\
\text { laevaniformans } \\
\text { 2.Micrococcus } \\
\text { yunnanensis }\end{array}$ & $\begin{array}{l}\text { 1. Microbacterium testaceum } \\
\text { 2. Bacillus safensis } \\
\text { 3. Bacillus subtillis }\end{array}$ & $\begin{array}{l}\text { 1. Microbacterium resistens } \\
\text { 2. Microbacterium testaceum } \\
\text { 3. Microbacterium } \\
\text { laevaniformans } \\
\text { 4. Brevibacterium epidermidis }\end{array}$ & 9 \\
\hline & - & $\begin{array}{l}\text { 1. Pseudomonas stutzeri } \\
\text { 2. Klebsiella } \\
\text { pneumoniae } \\
\text { 3. Agrobacterium } \\
\text { larrymoorei } \\
\text { 4. Bosea thiooxidans }\end{array}$ & $\begin{array}{l}\text { 1. Stenotrophomonas } \\
\text { maltophilia } \\
\text { 2. Pseudomonas denitrificans } \\
\text { 3. Enterobacter cancerogenus } \\
\text { 4. Methylobacterium } \\
\text { organophilum }\end{array}$ & $\begin{array}{l}\text { 1. Enterobacter cancerogenus } \\
\text { 2. Alcaligenes faecalis subsp. } \\
\text { faecalis } \\
\text { 3. Klebsiella variicola } \\
\text { 4. Pseudomonas moraviensis } \\
\text { 5. Rhizobium tarimense }\end{array}$ & 13 \\
\hline Total & & 23 & 16 & 34 & 73 \\
\hline
\end{tabular}

+: Gram positive bacteria; -: Gram negative bacteria 


\section{DISCUSSION}

The population of endophytic bacteria differed between location, age, rhizome, stem and leaf, and their diversity was also influenced by growth media. In this study, isolation of endophytic bacteria of white turmeric plant from three locations in West Java, Indonesia was done using two methods and four different media. Endophytic bacteria were succesfully isolated using four kinds of media, but addition of extract of white turmeric plants seemed to decrease population and diversity of endophytic bacteria. Among the four kinds of media used, NA was the suitable media for the endophytic bacteria isolation compared to WYEA. Based on the isolation method, the number of endophytic bacteria obtained using spread plate method was higher compared to plant piece method. This may caused by the differences in size and preparation of samples between the two methods. In the spread plate method, sample $\left(4-6 \mathrm{~mm}^{2}\right)$ were firstly ground to pieces and spread over the plate for bacterial growth. When the sample extracted using water, more microbes inside a plant moved to the water. This method seems to give more chance for endophytic bacteria to grow. While for the plant piece method the chance for endophytic bacteria to grow is limited because the sample $\left(4-6 \mathrm{~mm}^{2}\right)$ were directly put on media.

Several genera of bacteria can be found in three different locations, i.e. Microbacterium, Pseudomonas, Enterobacter, Bacillus, Stenothropomonas, Klebsiella, Mycobacterium, and Pantoea. Pseudomonas sp. and Bacillus sp. are the most abundant endophytic bacteria found in the plants. They are considered easy to be cultured (Seghers et al. 2004). The presence of microbes in a host plant can be affected by the compounds contained in the host plants (Strobel and Daisy 2003). The plants of the same species may produce relatively similar bioactive compounds (Bernhoft 2010).

Rhizome, stem and leaf from CBN had the lowest abundance of endophytic bacteria. The plant materials originally come from tissue culture which was subsequently domesticated in that place. It could be possible reason for limited numbers of endophytes. Endophytic bacteria of white turmeric plant from DRMG was more diverse compared to other samples. The differences may also be influenced by the different in ecological niche condition of the plant. The fact that more than one hundred of medicinal plants can be found in DRMG, may also influence the soil microbial diversity. Another reason which can influence the endophytes diversity is age of host plant. Sample taken from DRMG was the oldest (12 months), followed by sample from BG (11 months), and sample from CBN (8 months). As a mature plant developed, all the nutrients for the endophytic bacteria may be more available and abundance thus stable endophytic population can be obtained. Age of plants has been reported to influence the variation of endophytic community in the gingseng plants (Vendan et al. 2010).

Three plant materials of white turmeric plants showed different population of endophytic bacteria. The population on the rhizome of the plant was higher than those of the stems and leaves. The greater population found in the rhizome may be caused by the content of rhizome compounds. The plant uses the rhizome to store starch, protein, fat and other nutrients which are useful for the plant and its endosymbionts. Dalal and Kulkarni (2013) reported that population of endophytic microbes in roots or rhizome were the highest compared other part of plants, due to root is the earliest place for microbes entering the plant.

Among the 73 selected isolates, isolates belongs to the cluster of Gammaproteobacteria was the most dominant, followed by Actinobacteria, Alphaproteobacteria, Firmicutes, and Betaproteobacteria, they were $37,16,8,8,4$ respectively. The genera of Microbacterium was dominant, followed by Pseudomonas, Bacillus, Klebsiella and Enterobacter. In the present study, 73 endophytic bacteria which represented 46 species were belonging to 23 different bacterial genera have been identified from variously locations, aged, and part of plant of white turmerics. Cho et al. (2007) isolated 13 different bacterial genera of 63 endophytic bacteria from gingseng roots cultivated in three different areas. Vendan et al. (2010) isolated four clusters, 9 genera in 51 isolates from variously aged gingseng plants. Germida et al. (1998) reported that isolated 18 endophytic bacterial genera in 220 isolates from root tissues of three field-grown canolas. Thus, it seems that the diversity of endophytic bacteria in white turmeric plant collected from Bogor, West Java, Indonesia was more diverse compared to others result studies. In conclusion, that there are differences in the population and number of endophytic bacteria isolates recovered from white turmeric in Bogor, West Java, Indonesia and the isolates obtained depend on the location, age, part of plant, media and method of isolation. 


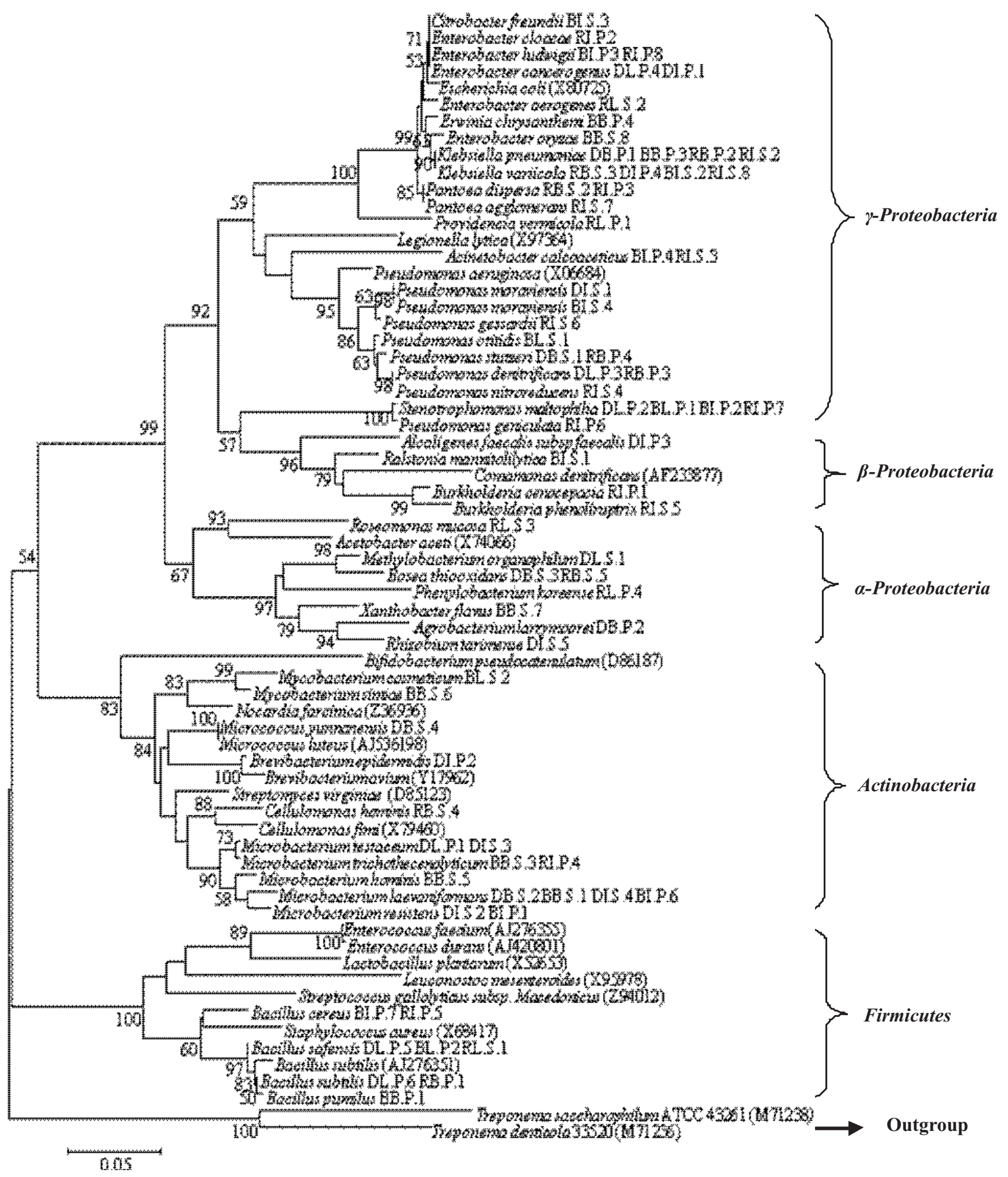

Fig 2 Phylogenetic tree based on 16S rDNA sequences of the endophytic bacteria using neighbor-joining tree method, model Kimura2-parameter and Gamma distributed with 1000 replications. 


\section{REFERENCES}

Banisalam B, Sani W, Philip K, Imdadul H, Khorasani A. 2011. Comparison between in vitro and in vivo antibacterial activity of Curcuma zedoaria from Malaysia. Afr J Biotech. 10(55):11676-11681. doi:10.5897/AJB10.962.

Bernhoft A. 2010. A brief review on bioactive compounds in plants. In: Bioactive compounds in plants - benefits and risks for man and animals. Symposium held at The Norwegian Academy of Science and Letters, 2008 Nov 13 - 14. Oslo. p 11-17.

Chen YT, Yuan Q, Shan LT, Lin MA, Cheng DQ, Li1 CY. 2013. Antitumor activity of bacterial exopolysaccharides from the endophyte Bacillus amyloliquefaciens $s p$. isolated from Ophiopogon japonicus. Oncol Lett. 5:1787-1792. doi: 10.3892/ol.2013.1284

Cho KM, Hong SY, Lee SM, Kim YH, Kahng GG, Lim YP, Kim H, Yun HD. 2007. Endophytic bacterial communities in ginseng and their antifungal activity against pathogens. Microb Ecol. 54:341-351. doi: 10.1007/s00248-007-9208-3.

Christina A, Christapher V, Bhore SJ. 2013. Endophytic bacteria as a source of novel antibiotics: An overview. Pharmacogn Rev. 7(13):11-16. doi: 10.4103/09737847.112833

Dalal J and Kulkarni N. 2013. Population dynamics and diversity of endophytic bacteria associated with soybean (Glycine max (L) Merril). Brit Microbiol Res J. 3(1):96-105.

Germida JJ, Siciliano SD, de Freitas JR, Seib AM. 1998. Diversity of root-associated bacteria associated with field-grown canola (Brassica napus L.) and wheat (Triticum aestivum L.). FEMS Microbiol Ecol. 26:4350 .

Joy PP, Thomas J, Mathew S, Skaria BP. 1998. Zingiberaceous Medicinal and Aromatic Plants. India: Aromatic and Medicinal Plants Research Station, Odakkali, Asamannoor P.O.

Lakshmi S, Padmaja G, Remani P. 2011. Antitumour effects of isocurcumenol isolated from Curcuma zedoaria rhizomes on human and murine cancer cells. Int J Med Chem. 2011:1-13. doi:10.1155/2011/253962.

Muthu-kumar T, Christy AMV, Mangadu A, Malaisamy M, Siviraj C, Arjun P, Raaman N, Balasubramanian K. 2012. Anticancer and antioxidant activity of Curcuma zedoaria and Curcuma amada rhizome extracts. J Acad Indus Res. 1(2):91-96.
Packeiser H, Lim C, Balagurunathan B, Wu J, Zhao H. 2013. An extremely simple and effective colony PCR procedure for bacteria, yeasts, and microalgae. Appl Biochem Biotech. 169:695-700. doi:10.1007/s12010012-0043-8.

Palaniappan P, Chauhan PS, Saravanan VS, Anandham R, $\mathrm{Sa}$ T. 2010. Isolation and characterization of plant growth promoting endophytic bacterial isolates from root nodule of Lespedeza sp. Biol Fert Soils. 46:807816. doi:10.1007/s00374-010-0485-5.

Procopio REL, Araujo WL, Maccheroni JW, Azevedo JL. 2009. Characterization of an endophytic bacterial community associated with Eucalyptus spp. Gen Mol Res. 8(4):1408-1422.

Pujiyanto S, Lestari Y, Suwanto A, Budiarti S, Darusman LK. 2012. Alpha-glucosidase inhibitor activity and characterization of endophytic Actinomycetes isolated from some indonesian diabetic medicinal plants. Int $\mathrm{J}$ Pharm Pharm Sci. 4(1):327-333.

Ryan RP, Germaine K, Franks A, Ryan DJ, Dowling DN. 2007. Minireview: Bacterial endophytes: recent developments and applications. FEMS Microbiol Lett. 278:1-9. doi:10.1111/j.1574-6968.2007.00918.x.

Seghers D, Wittebolle L, Top EM, Verstraete W, Siciliano SD. 2004. Impact of agricultural practices on the Zea mays L. endophytic community. Appl Environ Microbiol. 70 (3):1475-1482. doi : 10.1128/AEM.70.3.1475-1482.2004.

Srikandace Y, Hapsari Y, Simanjuntak P. 2007. Seleksi mikroba endofit Curcuma zedoaria dalam memproduksi senyawa kimia antimikroba. JIFI. $5(2): 77-84$.

Strobel G, Daisy B. 2003. Bioprospecting for microbial endophytes and their natural products. Microbiol Mol B i o l R e v . 67 ( 4 ) : $491-502$. d o i : 10.1128/MMBR.67.4.491502.2003.

Tamura K, Peterson D, Peterson N, Stecher G, Nei M, Kumar S. 2011. MEGA5: Molecular evolutionary genetics analysis using maximum likehood, evolutionary distance, and maximum parsimony methods. Mol Biol Evol. 28(10):2731-2739. doi:10.1093/molbev/msr121.

Vendan RT, Yu YJ, Lee SH, Rhee YH. 2010. Diversity of endophytic bacteria in ginseng and their potential for plant growth promotion. J Microbiol. 48(5):559565.doi:10.1007/s12275-010-0082-1. 